\title{
Predictors of Employee Motivation in a Pharmaceutical Company
}

\author{
Jie Cai Wenxi Tang \\ China Pharmaceutical University; School of International Pharmaceutical Business, Department of Business \\ Management
}

The research is financed by Jie Cai

\section{Abstract}

The researcher sought to find out the predictors of employee motivation in the Taro Pharmaceutical Company. The research design for this study was a cross-sectional descriptive survey with a close ended questionnaire which was used to provide answers to the research questions. The independent variable in the study is HR Strategies and the dependent variable in the study is employee motivation. The study employed Statistical Package for Social Sciences (SPSS) version 20.0 to analyze the data gathered on the basis of descriptive statistics such as Mean and Standard deviation and inferential statistics thus, Pearson correlation and regression and the result was discussed. Systematic and proportionate sampling techniques were used in selecting 242 respondents. 215 questionnaires were retrieved and used for the analysis. To test hypotheses $\mathrm{H} 1-\mathrm{H} 2$, bivariate regression analyses was carried out. Also, Pearson correlation was done to find out the existing relationship between HR Strategies and employee motivation. HR Strategies was significantly related to employee motivation. in the simple regression analysis, all the dimensions of HR Strategies significantly impacted employee motivation with communication being the highest predictor of motivation. The results revealed that, at the Taro Pharmaceutical Company, HR Strategies include communication, reward and recognition, work systems, staffing and training and development. The results proved that; all the dimensions of HR Strategies were significantly related to employee motivation which shows that employees were highly motivated. staffing and training and development followed with reward and recognition as well as work system. The highest of the challenges is non-regularization of a general staff meeting. Also, the absence of lucrative incentives was a major challenge to the employees. Inadequate change within work unit was also key. Even though employees were motivated generally, Low comprehension of company strategy and poor coordination amongst management was evident in the results of the analysis. Based on the findings, the researcher recommends that, Management should consider regularizing general meetings with the entire staff. Certain concerns of low-profile staff may be better understood at a general meeting even though there are structured ways of presenting their grievances. Management should also consider incentivizing lower ranked employees and other employees who fall outside the top management bracket. It is research based and healthy for employees to be incentivized intermittently.

Keywords: Human Resource Strategy, Employee Motivation

DOI: $10.7176 / \mathrm{EJBM} / 13-3-12$

Publication date: January $31^{\text {st }} 2021$

\section{Introduction}

HR strategies set out what the organization intends to do about its human resource management policies and practices and how they should be integrated with the business strategy and each other. They are described by Dyer and Reeves (1995) as 'internally consistent bundles of human resource practices. Richardson and Thompson (1999) suggest that:

A strategy, whether it is an HR strategy or any other kind of management strategy must have two key elements: there must be strategic objectives (ie things the strategy is supposed to achieve), and there must be a plan of action (ie the means by which it is proposed that the objectives will be met).

The purpose of HR strategies is to articulate what an organization intends to do about its human resource management policies and practices now and in the longer term, bearing in mind the dictum of Fombrun et al (1984) that business and managers should perform well in the present to succeed in the future. HR strategies aim to meet both business and human needs in the organization. Studies on motivation depicts that there are several ways to motivate employees. These are known as theories, which can be divided into two categories. They are the content theories and the process theories. The content theory focuses on what motivates employees and it was propounded by eminent writers such as Maslow (1946), Mcclelland (1988) and Hertzberg (1968). Vroom (1969), Adams (1965), Locke and Lathan (1990) are the proponents of the process theories. The foregoing begs the following questions: What are the prevailing HR Strategies existing in the Taro Pharmaceutical Company? What is the impact of HR Strategies on employee motivation in the Taro Pharmaceutical Company? There are several ways in which this study will be of importance and add to collective research literature.

\subsection{Conceptual Framework}


Conceptual framework depicts a systematic way of organizing a particular project, study, research or activity (Mugenda \& Mugenda, 2006). It involves providing an understanding of the various features of the activity. According to Mittal, et al., (2010), a framework offers an explanation of why a particular activity or research is being undertaken in a particular way. It again aids in the application of ideas of others and in particular a framework can help us to explain why we are doing a project in a particular way. A framework exemplifies a map which gives direction as regards the roads, and other routes that allows passengers to go to a particular place (Mugenda \& Mugenda, 2006).

From the extant literature, the researcher identified a couple of HR Strategies which are applied in this study. These are staffing, Training, Rewards and Recognition, Work systems, communication and employee relation. The researcher therefore has come out with the conceptual framework which is illustrated below.

Human resource strategy is identified as the independent variable and employee motivation as the dependent variable. HR strategies has been attributed six (6) dimensions. These dimensions independently influence the employee. Such an influence on the employee motivation could ultimately lead to whether the employee is highly motivated, moderately motivated or not motivated. It is expected that, by the interrelation of these variables, the researcher will be able to conclusively identify what impact HR strategy at the Taro Pharmaceutical company has had on the employees.

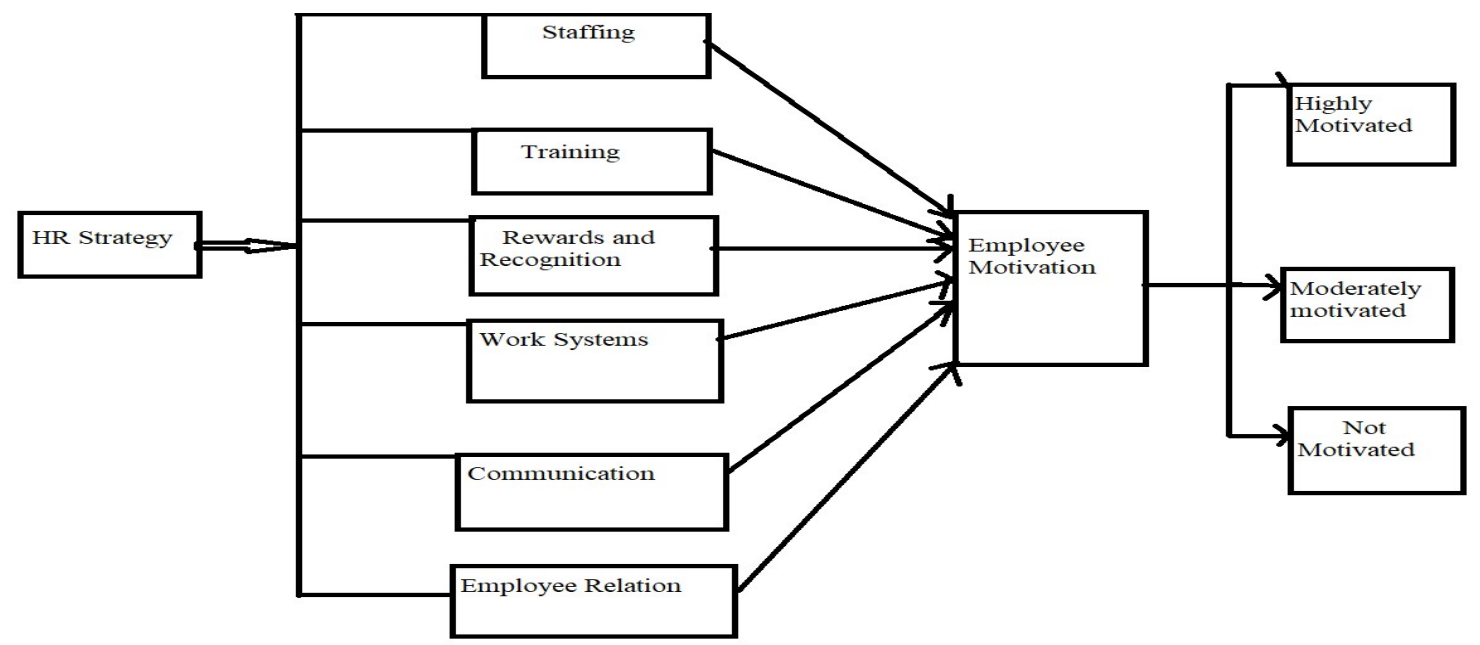

Figure 1: Conceptual Framework, Source: Author's Literature Survey, 2019

2.0 Research Objectives

2.1 Identify the HR Strategies existing in the Taro pharmaceutical company.

2.2 To assess the impact of HR Strategies on employee motivation in the Taro Pharmaceutical Company.

\subsection{Theoretical Framework of the Study}

A lot of theories have been propounded to examine the factors that contribute to employee motivation in organizations. These theories are important because they provide explanations to the reasons why employees are motivated, therefore, if properly looked at, could lead to having better motivated employees which ultimately may lead to increased productivity in organizations (McCullagh, 2005).

\subsection{Herzberg and Maslow}

Herzberg (1959) introduced a well-known motivation theory, which is the two-Factor Theory, he described in his theory between motivators and hygiene factors. He emphasized that the factors can either be motivators or hygiene factors, but can never be both at the same time. Intrinsic motivational factors are challenging work, recognition and responsibilities. Hygiene motivators are extrinsic motivational factors such as status, job security and salary. Motivating factors can, when present, leads to satisfaction and Hygiene factors can, when not present leads to dissatisfaction, but the two factors can never be treated as opposites from each other (Saiyadain 2009, 158).

\subsection{Process Theory}

The emphasis in process theory is on the psychological processes or forces that affect motivation, as well as basic needs (Armstrong, 2010). The process theory is also known as cognitive theory because it is concerned with people's perceptions of their working environment and the ways in which they interpret and understand it (Armstrong, 2010).

According to Armstrong (2010), process theory provides a much more relevant approach to motivation. 
Central to the process theory is a series of cognitive theories that attempt to understand the thought processes that people have when determining how to behave in the workplace (Steers \& Shapiro, 2004). One of the known cognitive theories is the expectancy theory presented by Victor Vroom as the first systematic formulation of the theory (Steers \& Shapiro, 2004). Following Vroom's expectancy theory are other process theories such as the goal achievement theory and equity theory.

\subsection{Expectancy Theory}

In Spector (2000), expectancy theory explains how rewards lead to behavior by focusing on internal cognitive states that lead to motivation. According to Daft (2003, in Dartey-Baah, 2010), expectancy theory proposes that motivation depends on the individuals' expectations or outlook about their ability to perform tasks and receive desired rewards.

The theory was originally contained in the valency-instrumentality-expectancy (VIE) theory which was formulated by Vroom (1964, in Green, 2000). Valency stands for value; instrumentality is the belief that if one thing is done, it leads to another, and expectancy is the probability that action or effort will lead to an outcome (Vroom, 1964). The theory assumes that people think about what they are doing, what they are getting and its worth (Armstrong, 2010). Vroom's expectancy theory (Vroom, 1964) developed the topic of motivation combining the interaction of individual needs and employees working together.

The concept of expectancy theory was defined in more detail by Vroom (1964) as follows:

When an individual chooses between alternatives which involve uncertain outcomes, it seems clear that this behaviour is affected not only by his preferences among these outcomes but also by the degree of to which he believes these outcomes to be possible. Expectancy is defined as a momentary belief concerning the likelihood that a particular act will be followed by a particular outcome. Expectancies may be described in terms of their strength. Maximal strength is indicated by subjective certainty that the act will be followed by the outcome, while minimal (or zero) strength is indicated by subjective certainty that will not be followed by the outcome.

The strength of expectations may be based on past experiences (reinforcement), but individuals are frequently with new situations - a change in job, payment system, or working conditions imposed by management - where past experience is not an adequate guide to the implications of the change. In these circumstances, motivation may be reduced (Armstrong, 2010).

\subsection{Methods}

The research design for this study was a cross-sectional descriptive survey with a close ended questionnaire which was used to provide answers to the research questions. The independent variable in the study is HR Strategies and the dependent variable in the study is employee motivation.

This study employed a quantitative research design to investigate the relationship existing between the various human resource strategies and employees' motivation and also to find out the impact human resource strategies have on employee's motivation. The empirical analysis for the study aimed at finding out the relationship between human resource strategy and employees' motivation in the Taro company Ltd in Canada.

The study employed Statistical Package for Social Sciences (SPSS) version 20.0 to analyze the data gathered on the basis of descriptive statistics such as Mean and Standard deviation and inferential statistics thus, Pearson correlation and the result was discussed. Two hundred and forty-two (242) senior staff members including supervisors and managers participated in the research. Persons each drawn from the respective levels (senior management, middle level management, lower level and supervisory level management were involved in the exercise. Since the population at the Taro Company is a finite population, the researcher used the systematic sampling technique and proportionate which is a probability sampling method. With this method, list of the various level of employees was sourced from the HR department and numbers sequentially drawn from one to the last person according to each level.

The expected sample size was 242 and simple random sampling was used to select the required number to partake in the research activity. Proportionate sampling technique was used to give equal representation to the various level of employees.

The researcher consulted the HR department for the nominal roll of staff. The total number of staff are 661 . The researcher collected the nominal roll of the different levels of employee and calculated for the sampling interval. The formular for sampling interval is given by the entire population over desired sample size. 661/242= 2.73. Rounding it to a whole figure, the sampling interval is 3.0. This means that, taking the nominal roll of each level of management, every $3^{\text {rd }}$ person on the list counting from the start point was administered the questionnaire. The researcher made frantic efforts to involve all the staff who were selected using the systematic sampling technique until the last respondent was administered with the questionnaire. The 242 sample is backed by the Krejcie \& Morgan, (1970) sampling distribution according to sizes of population. In this instance, the population is 661 . According the chart, 661 should have a sample of 242 to make the sample scientific. Find below the chart. 


\begin{tabular}{|c|c|c|c|c|c|}
\hline & & & & & \\
\hline & 10 & $2 \geq 0$ & $1-5$ & 1200 & \\
\hline 15 & 14 & 230 & 144 & $1=a n$ & 297 \\
\hline 20 & 24 & 240 & 148 & 10 & 302 \\
\hline 品 & $\exists z$ & ב6! & $1=5$ & 1 ana & 310 \\
\hline$\exists$ & 3 & 370 & $1 \rightarrow 0$ & $1 \mathrm{Na}$ & 313 \\
\hline 45 & 36 & $\begin{array}{ll}2 \\
2\end{array}$ & 162 & 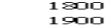 & 320 \\
\hline 5 & 44 & 300 & 169 & 20000 & 322 \\
\hline 5 & $\begin{array}{l}48 \\
32\end{array}$ & 320 & 131 & $\begin{array}{l}2 \\
=0000\end{array}$ & $\begin{array}{l}327 \\
331\end{array}$ \\
\hline$=5$ & 50 & 300 & $1 \geqslant 0$ & 30000 & 335 \\
\hline 75 & 63 & -400 & 196 & 30000 & 341 \\
\hline 80 & 56 & 420 & 201 & $\begin{array}{l}3 \\
30000\end{array}$ & $\begin{array}{l}346 \\
351\end{array}$ \\
\hline 90 & $x=$ & $4 \pi 0$ & 210 & 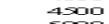 & 354 \\
\hline 5 & In & 50 & 214 & 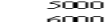 & $35 \pi$ \\
\hline $\begin{array}{l}110 \\
110\end{array}$ & 8 & $>50$ & 217 & 90 & $\begin{array}{l}361 \\
364\end{array}$ \\
\hline $1 \geq 0$ & 92 & $\sin$ & 234 & 80000 & 367 \\
\hline $\begin{array}{l}130 \\
130\end{array}$ & 197 & $\begin{array}{l}650 \\
300\end{array}$ & $\begin{array}{l}242 \\
248\end{array}$ & 1900 & $\begin{array}{l}368 \\
370\end{array}$ \\
\hline $\begin{array}{l}1>0 \\
1=0\end{array}$ & $\begin{array}{l}108 \\
11\end{array}$ & 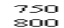 & 골영 & $1=0$ & 33 \\
\hline & $\begin{array}{lll}1 & 1 & 3 \\
1 & 1 & 3\end{array}$ & $\leqslant \leq \square$ & $\begin{array}{l}260 \\
365\end{array}$ & 3 & 378 \\
\hline $1 \approx 0$ & 123 & 900 & 209 & 40000 & 380 \\
\hline 1900 & $\begin{array}{l}127 \\
132\end{array}$ & 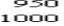 & 274 & 35000 & 381 \\
\hline$=10$ & 130 & & & & \\
\hline
\end{tabular}

\subsection{Results}

\subsection{Descriptive Characteristics of Respondents}

\section{Descriptive Statistics of the Respondents}

The main objective of descriptive analysis is to understand the profile of the respondents. Table 1.1 shows a summary of the descriptive analysis.

From Table 1.1, the preponderance of the respondents aged between 26-31 (51.6\%). This was followed by the age range from 20-25 (20.9\%). The least represented age group is 44 years and above $(4.2 \%)$. Majority of the gender were males $(79.1 \%$ ) with females recording $20.9 \%$. On the educational background of employees, preponderance was tertiary level $(54.9 \%)$. Few were unlettered and had no formal education $(1.4 \%) .35 .3 \%$ of the respondents were secondary or Middle School Living Certificates earners. On the religious background of the respondents, $72.6 \%$ of the employees were Christians. Islam followed with $16.3 \%$. Budhists $(7.4 \%)$ and Traditionalist $(3.7 \%)$. The religious picture shows that, there is variety in terms of employee religious affiliations. Duration of their working experience was explored by the researcher. Most (39.5\%) of the respondents had worked for between 15 years. They were followed by those who had worked for 6-11 years $(35.3 \%)$. Those who had worked from $12-$ 17 years represented $23.3 \%$ with the least represented being those who had worked for 18 years and above $(1.9 \%)$.

Table 1.1 Demographic Profile of Respondents

\begin{tabular}{|c|c|c|c|c|c|c|c|}
\hline Variable & Category & Frequency & Percentage & Mean & SD & Skewness & Kurtosis \\
\hline \multirow{5}{*}{ Age } & $20-25$ & 45 & 20.9 & & & & \\
\hline & $26-31$ & 111 & 51.6 & & & & \\
\hline & $32-37$ & 40 & 18.6 & & & & \\
\hline & $38-43$ & 10 & 4.7 & & & & \\
\hline & 44 and above & 9 & 4.2 & 2.20 & & 1.06 & 1.30 \\
\hline \multirow[t]{2}{*}{ Gender } & Male & 170 & 79.1 & 1.21 & 0.41 & & \\
\hline & Female & 45 & 20.9 & & & 1.44 & 0.07 \\
\hline Educational & Formal & & & & & & \\
\hline \multirow[t]{5}{*}{ Background } & Education & 3 & 1.4 & & & & \\
\hline & Primary & 7 & 3.3 & & & & \\
\hline & JHS & 11 & 5.1 & & & & \\
\hline & Secondary/MSLC & 76 & 35.3 & & & & \\
\hline & Tertiary & 118 & 54.9 & 4.39 & 0.84 & -1.75 & 3.55 \\
\hline \multirow[t]{4}{*}{ Religion } & Christianity & 156 & 72.6 & & & & \\
\hline & Islam & 35 & 16.3 & & & & \\
\hline & Buddhist & 16 & 7.4 & & & & \\
\hline & Traditionalist & 8 & 3.7 & 1.42 & 0.79 & 1.88 & 2.73 \\
\hline \multirow[t]{4}{*}{ Experience } & $1-5$ years & 85 & 39.5 & & & & \\
\hline & $6-11$ years & 76 & 35.3 & & & & \\
\hline & $12-17$ years & 50 & 23.3 & & & & \\
\hline & 18 and above & 4 & 1.9 & 1.87 & 0.83 & 0.44 & -0.91 \\
\hline
\end{tabular}

In assessing whether the data of this study were normally distributed, kurtosis and skewness index were employed for each variable. According to Kline (2005), absolute values of skewness index less than 3 and the kurtosis index below 10 suggest that the data is normally distributed. As indicated in Table 4.2, the skewness and kurtosis indexes exposed that all the variables were normally distributed with the skewness and kurtosis absolute values ranging from 0.44 to 1.88 , and 0.07 to 3.55 respectively. Finally, reliability analysis was conducted to find 
out the internal consistency of each of the measuring instrument of the variables under investigation. It was revealed that all the variables have satisfactory Cronbach's alpha. As Nunnally and Bernstein (1994) suggested, the Cronbach's alpha should be greater than or equal to .70 before the instrument can be deemed reliable. As presented in Table 1.2, the Cronbach's alpha of the study ranged from 0.94 to 0.96 which indicates that the instruments were reliable.

Table 1.2 Reliability

\begin{tabular}{llllll}
\hline Variables & No. of Items & Cronbach Alpha & Mean & Skewness & Kurtosis \\
\hline HR Strategies & 25 & 0.96 & 3.88 & -1.35 & 0.77 \\
Employee & 9 & 0.94 & 3.80 & -1.23 & 0.33 \\
Motivation & & & & \\
\hline
\end{tabular}

\subsection{HR Strategies}

The table 1.3 shows the mean score and standard deviation of human resource strategies implemented in Taro Pharmaceutical Company. This was necessary to unravel the opinions of management on one hand, and employees, on another hand as regards the availability and attractiveness of human resource strategies in the said company. When it comes to communication as a dimension of human resource strategies, most of the management of Taro company strongly agree that communication flows very well in the company with the mean score of 4.73 whereas most of the employees also agree that communication is good in the company with the mean score of 3.90. The views shared by these two different groups suggest that communication flows very well in Taro Pharmaceutical Company but management is more convinced than employees as shown in the table 1.3.

With regards to training and development as another dimension of human resource strategies, management of Taro Pharmaceutical Company is in very strong agreement that the company has attractive training and development opportunities for its employees with the mean score standing at 4.6 meanwhile most of the employees agree that the company offers them training and development opportunities. Here, it was seen that management shared relatively stronger view than employees.

Again, concerning how the company rewards and recognize the effort of its staff, management agree that the company indeed has attractive compensation and reward practices for its workers with the mean score of 4.10. Employees, on the other hand, posit that the company rewards and recognizes their effort handsomely even though few of them were not sure as to whether the company rewards and recognition packages is attractive or not. Again, it could be seen that management held a stronger view on this than employees. Moreover, management of Taro Pharmaceutical Company is of the opinion that the work system within the company is smooth with the mean of 4.47. This means that most of the management members agree that the company has a smooth work system and only few strongly agree that the work system prevailing in the company is good. In a similar direction, most of the employees of the company agree that work system is smooth but few of them were uncertain with the mean of 3.83 .

Finally, pertaining to staffing as a dimension of human resource strategies, all of the management members strongly agreed that the company has good staffing procedures for its recruitment and selection with the mean of 5.00. Meanwhile, most of the employees of the company only agreed that the staffing processes and procedures of the company is good but only few of them were not sure as to whether the staffing procedures and processes were good or not with the mean of 3.83 .

It can therefore be concluded that, comparatively, management of Taro Pharmaceutical Company at all times shared relatively stronger views concerning the availability and attractiveness of human resource strategies than employees. Nevertheless, employees took a similar stance with management on the issues of human resource strategies existing in the Taro Pharmaceutical Company. The researcher did not find employee relations as was proposed from literature in the conceptual framework. The applicable HR Strategies were limited to communication, training and development, reward and recognition, staffing and work systems.

\begin{tabular}{lllll}
\multicolumn{4}{l}{ Table 1.3: Mean Score and Standard Deviation of Human Resource Strategies for Mgt \& Employees } \\
\hline Variable: & Mgt(Mean) & Employees(Mean) & SD(Mgt) & SD(Emp.) \\
\hline Communication & 4.7333 & 3.9039 & .27889 & .87084 \\
Training and Development & 4.6000 & 3.9116 & .28504 & .89572 \\
Reward and Recognition & 4.1000 & 3.9093 & .09129 & .96177 \\
Work System & 4.4667 & 3.8326 & .18257 & 1.15689 \\
Staffing & 5.0000 & 3.8337 & .00000 & .92567 \\
\hline
\end{tabular}

\subsection{Regression Analysis}

A simple linear regression analysis was further used to determine whether human resource strategies will predict employee motivation. Table 4.5 gives a summary of the simple regression analysis.

$\boldsymbol{H} 2$ : HR Strategies will significantly impact employee motivation.

Pearson simple regression analysis was conducted to predict employee motivation based on Human resource 
strategies. Results of the regression analysis as shown in Table 4.5 reveals that human resource strategies (communication, training and development, reward and recognition, work system, and staffing) is a positive and significant predictor of employee motivation $(\beta=.924, p<.01)$ in the Taro Pharmaceutical Company. Additionally, human resource strategies accounted for $85.4 \%$ of the variation in employee motivation. However, all the dimensions of human resource strategies were seen to significantly impact employee motivation with communication being the highest predictor $\left(\beta=.901, \mathrm{p}<.01\right.$ and $\left.\mathrm{R}^{2}=.812\right)$, followed by staffing $(\beta=.880, \mathrm{p}<.01$ and $\left.\mathrm{R}^{2}=.775\right)$, training and development $\left(\beta=.827, \mathrm{p}<.01\right.$ and $\left.\mathrm{R}^{2}=.683\right)$, reward and recognition, $(\beta=.827, \mathrm{p}<$ .01 and $\left.\mathrm{R}^{2}=.683\right)$ and work system $\left(\beta=.662, \mathrm{p}<.01\right.$ and $\left.\mathrm{R}^{2}=.438\right)$. Therefore, the hypothesis 2 was confirmed by the regression analysis. The result of the regression analysis means that as human resource strategies of Taro Pharmaceutical Company improves the more likely it is to augment higher levels of motivation among its employees.

\begin{tabular}{|c|c|c|c|c|}
\hline Model & Variable Entered & R Square $\left(\mathrm{R}^{2}\right)$ & F-Value & $\operatorname{Beta}(\beta)$ \\
\hline 1 & (Constant) & & & \\
\hline 2 & $\begin{array}{l}\text { Communication } \\
\text { (Constant) }\end{array}$ & .812 & 918.897 & .901 \\
\hline 3 & $\begin{array}{l}\text { TD } \\
\text { (Constant) }\end{array}$ & .683 & 459.70 & .827 \\
\hline & $\mathrm{RR}$ & .683 & 459.806 & .827 \\
\hline 4 & $\begin{array}{l}\text { (Constant) } \\
\text { WS }\end{array}$ & .438 & 166.188 & .662 \\
\hline 5 & $\begin{array}{l}\text { (Constant) } \\
\text { Staffing }\end{array}$ & .775 & 733.543 & .880 \\
\hline 6 & $\begin{array}{l}\text { (Constant) } \\
\text { HRS }\end{array}$ & .854 & 1249.974 & .924 \\
\hline
\end{tabular}

Note: $N=215 ; p<.01 . \mathrm{DV}$ is employee motivation. Predictors are communication, training and development, reward and recognition, work system, staffing and human resource strategy.

\subsection{Discussion of Findings}

6.1 Discussion of Objective One

The first objective of the study sought to identify the HR Strategies existing in the Taro pharmaceutical company. The results revealed that, at the Taro Pharmaceutical Company, HR Strategies include communication, reward and recognition, work systems, staffing and training and development. The responses from both management and employees were evident. most of the management of Taro company strongly agree that communication flows very well in the company whereas most of the employees also agree that communication is good in the company. The views shared by these two different groups suggest that communication flows very well in Taro Pharmaceutical Company but management is more convinced than employees.

With regards to training and development as another dimension of human resource strategies, management of Taro Pharmaceutical Company is in very strong agreement that the company has attractive training and development opportunities for its employees. Meanwhile most of the employees agree that the company offers them training and development opportunities. Here, it was seen that management shared relatively stronger view than employees.

Again, concerning how the company rewards and recognize the effort of its staff, management agree that the company indeed has attractive compensation and reward practices for its workers. Employees, on the other hand, posit that the company rewards and recognizes their effort handsomely even though few of them were not sure as to whether the company rewards and recognition packages is attractive or not. Again, it could be seen that management held a stronger view on this than employees. Moreover, management of Taro Pharmaceutical Company is of the opinion that the work system within the company is smooth. This means that most of the management members agree that the company has a smooth work system and only few strongly agree that the work system prevailing in the company is good. In a similar direction, most of the employees of the company agree that work system is smooth but few of them were uncertain.

Finally, pertaining to staffing as a dimension of human resource strategies, all of the management members strongly agreed that the company has good staffing procedures for its recruitment and selection. Meanwhile, most of the employees of the company only agreed that the staffing processes and procedures of the company is good but only few of them were not sure as to whether the staffing procedures and processes were good or not.

It can therefore be seen that, comparatively, management of Taro Pharmaceutical Company mostly shared stronger views concerning the availability and attractiveness of human resource strategies than employees. Nevertheless, employees took a similar stance with management on the issues of human resource strategies existing in the Taro Pharmaceutical Company. The researcher did not find employee relations as was proposed 
from literature in the conceptual framework.

However, the following section also tries to discuss the results of each of the hypothesis tested.

\subsection{Discussion of Objective Two}

The researcher as part of the objectives sought to assess the impact of HR Strategies on employee motivation in the Taro Pharmaceutical Company. This necessitated regression analysis to find out the extent each dimension of HR Strategies impact employee motivation. The researcher hypothesized that; $\boldsymbol{H} 2$ : HR Strategies will significantly impact employee motivation.

Results of the regression analysis as shown in Table 4.5 reveals that human resource strategies (communication, training and development, reward and recognition, work system, and staffing) is a positive and significant predictor of employee motivation. However, of all the dimensions of human resource strategies seen to significantly impact employee motivation, communication was the highest predictor of employee motivation. Staffing and training and development followed with reward and recognition as well as work system. The study shows explicitly that, employees are highly motivated.

Surprisingly, communication was seen as the best predictor of employee motivation. The outcome of this study corroborates other studies. In a study by Kirti (2012) on Effective Organizational Communication: a Key to Employee Motivation and Performance using interviews of the employees of Vanaz Engineers Ltd and communication efforts recording sheets given to them, The interviews and the communication efforts sheets were completed by 10 percent of the company population, randomly selected according to each department's population base. From the analysis of the information received, it was found that Vanaz implements various effective organizational communication practices which contribute a lot to motivate its employees and increase their performance and loyalty towards the organization.

In another study, Sirota, Mischkind and Meltzer (2006), found that managers who communicate openly and regularly see large increases in employee morale. Effective communication needs to take place in businesses that attempt to empower their employees, giving them authority and extending their roles. It is essential that employees are aware of the organization's goals and understand why they are put in place. They must also understand how their jobs contribute to meeting these objectives and how well they are performing. This will allow them to determine how much they are contributing to the success of the business. Both formal and informal communication where there's a feedback involved, it is an important part of employee motivation. By using effective communication in this way, it is likely that management will have a much more committed and focused workforce. Employees that are highly motivated are more likely to communicate more openly with management by putting forward suggestions or ideas, listening to advice and contributing their own opinions (Kinicki \& Kreitner, 2006). A survey from Opinion Research Corporation, an info GROUP company (2011) indicates that employees are two times as likely to go the extra mile for the organization and almost four times as likely to recommend their company if they are satisfied with the ways in which their company communicates difficult decisions.

Executives build employee confidence in leadership's capability by helping employees through communication to understand the company's general strategy and to identify their particular contribution to executing it. Managers don't just deliver marching orders they explain how the tactics help the team and total company complete the assigned mission says John T. Williams, Just as executives can exploit different communication styles to shape a company's vision, managers can adapt their interaction style to motivate diverse departments or teams. Effective communication, with managers taking the lead, fosters trust within the workforce, which leads to a more compelling exchange of ideas, helps staff to embrace more responsibility, and encourages management to stretch for higher targets. According to Grunig (as cited in Chen, 2008), the key in creating and maintaining good and harmonious relations between employees and the management in the process of high-quality communication is more directed to symmetric communication than asymmetric communication.

Similarly, on rewards and recognition, a study on the Impact of Rewards and Recognition on Employee Motivation by Baskar \& Rajkumar (2014) using descriptive research design on 50 employees as the sample size by using 'convenience sampling revealed significantly direct and positive relationship between rewards and recognition and job satisfaction and motivation.

The current study found staffing as one of the dimensions of HR Strategies significantly related to employee motivation. One of the staffing objectives has always been and has been advocated for ensuring that people are recruited, they should be retained (Ghauri \& Prasad 1995, 354 - 355) and this objective can be implemented with the right people in place. The staffing function will affect almost all other HR functions because all functions will move towards the direction of staffing policies (Hendry 1994, 80 - 88).

Staffing was significantly related to employee motivation in the current study. One of the staffing objectives has always been and has been advocated for ensuring that people are recruited, they should be retained (Ghauri \& Prasad 1995, 354 - 355) and this objective can be implemented with the right people in place. The staffing function will affect almost all other HR functions because all functions will move towards the direction of staffing policies (Hendry 1994, 80 - 88). 


\subsection{Conclusion}

In relation to the main findings outlined, the following conclusions were drawn.

The main HR Strategies at the Taro Pharmaceutical Company, include communication, reward and recognition, work systems, staffing and training and development.

It was established from the results that, communication is the highest predictor of employee motivation. staffing and training and development followed with reward and recognition as well as work system.

The main challenge to HR Strategies is non-regularization of a general staff meeting. Also, the absence of lucrative incentives was a major challenge to the employees. Inadequate change within work unit was also key. Even though employees were motivated generally, Low comprehension of company strategy and poor coordination amongst management was evident in the results of the analysis.

\subsection{Recommendation}

Based on the findings, the researcher recommends that, Management should consider regularizing general meetings with the entire staff. Certain concerns of low-profile staff may be better understood at a general meeting even though there are structured ways of presenting their grievances.

Management should also consider incentivizing lower ranked employees and other employees who fall outside the top management bracket. It is research based and healthy for employees to be incentivized intermittently.

Again, the study proffers that, introduction of some level of dynamism should be introduced to various units to allow for changes in roles and responsibilities. Internal arrangements are thus laudable to remove boredom in the system.

The researcher submits that, intensification of communication as a strategy of HR is helpful in achieving the goals of the company. Since most of the employees were happy about the communication strategy, management should intensify this strategy to allow a directional and goal-oriented crop of employees.

The researcher recommends that, even though the identified HR Strategies were functioning well, not all the dimensions were able to score high rating as some of the employees were unsure of the applicable strategies. Hence, management should intensify the existing strategies to help achieve organizational goals.

\section{References}

Ahmed, R. R., Warraich, U. A., Khoso, I., \& Ahmad, N. (2014). Impact of stress on job performance: an empirical study of the employees of private sector universities of Karachi. Global Management Journal for Academic and Corporate Studies, 4(2), 104-108.

Akhtar et al. (2008). Human resource Management,Wiley periodicals Inc.Vol.47:1: 15-32.

Armstrong, M. (2012). Armstrong's handbook of Human Resource Management Practice, Kogan Page

Armstrong, M. (2009), Armstrong's handbook of Human Resource Management Practice, Kogan Page.

Baum, N.\& Zablocki, E. (1996). Take charge of your medical practice before someone else does it for you. Aspen Publications, Inc.

Binder, Jean Carlo 2007. Global project management: Communication, collaboration and management. Grower Publishing Limited.

Block, Peter 2005. Stewardship: Choosing service over self-interest. Berrett-Koehler Publishers, Inc.

Boru, H. R. (2008). A Survey on the extent of adoption of the SHRM Practices among NGOs in Kenya (Unpublished MBA Project), UON, Kenya

Boxall, P. F. and Purcell, J. (2003). Strategy and Human Resource Management, Palgrave.

Bruce, A. (2006). How to Motivate Employees: 24 Proven Tactics to Spark Productivity in the Workplace. NY, McGraw Hill Professional.

Chew and Chong (2011). Effects of Strategic Human Resource Management on Strategic Vision, International Journal of HRM.

Crouse, N. (2005). Motivation is an Inside Job: How to Really Get Your Employees to Deliver the Results You Need. Oxford, Universe.

Delery, J.E and Doty D. H (1996). Modes of Theorizing in Strategic Human Resource Management: Tests of Univerlistic, Contingency and Configurational Predictions, Academy of Management Journal.

Dessler, G (2013). Human Resource Management, Pearson Education Ltd.

Fombrun et al. (1984). Strategic Human Resource Management, John Wiley \& Sons, Inc.

Foot, M and Hook, C (2010). Introducing Human Resource Management, Prentice- Hall.

Gomez-Mejia et al. (2010). Managing Human Resources, Pearson Education, Inc. Grant, R.M. (1991); The Resource- Based theory of Competitive Advantage: Implications for Strategy Formulation, California Management.

Hiam, A. (2003). Motivational Management: Inspiring Your People for Maximum Performance. NY, AMACOM. 
Huselid, M. A. (1995). The Impact of Human Resource Practices on Turnover, Productivity and Corporate Financial Performance, Academy of Management Journal.

Katou, A.A. (2008). Measuring the impact of HRM on Organizational performance. Journal of Industrial Engineering and Management, Retrieved 20 September, 2019

Kombo, D and Tromp, D (2006). Proposal and Thesis Writing: An Introduction, Paulines Publications Africa.

Kuranchie-Mensah, Elizabeth Boye; Amponsah-Tawiah, Kwesi (2016) : Employee motivation and work performance: A comparative study of mining companies in Ghana, Journal of Industrial Engineering and Management (JIEM), ISSN 2013-0953, Omnia Science, Barcelona, Vol. 9, Iss. 2, pp. 255-309.

Latham, G. (2011). Work Motivation: History, Theory, Research and Practice. NJ, SAGE.

Lauby, S. (2005). Motivating Employees: Career Planning \& Talent Management. Washington DC, American Society for Training and Development.

Machado and Davim (2014). Management and Industrial Engineering Work organizations and HRM, Springer International Publishing, Switzerland.

Mansaray, H. E. (2019). The Role of Human Resource Management in Employee Motivation and PerformanceAn Overview. Budapest International Research and Critics Institute (BIRCI-Journal): Humanities and Social Sciences, 2(3), 183-194.

Melchor, H (2013). The Government Workforce of the Future: Innovation in Strategic Workforce Planning in OECD Countries: OECD Working Papers on Public Governance No.21, OECD Publishing.

Mkalama, R. N. (2010). SHRM Practices adopted by Water Service providers within Athi Water services Board (Unpublished MBA Project), UON, Kenya.

Mugenda and Mugenda (2003). Research methods: Quantitative and Qualitative Approaches, Nairobi Acts Press.

Mutsuddi, I. (2012). Managing Human Resources in the Global Context, Delhi.

Mwatete, R (2012). Challenges of Implementing Strategic HRM at Kenya Sugar Board ( Unpublished MBA Project) UON, Kenya .

Neely, A. (2007). Business performance measurement: Unifying theory and integrating practice (2nd ed.). London, UK: Cambridge University Press,

Noe et al.(2010). Human resource Management, McGraw Hill

Ngechu, M. (2004). Understanding the Research Process and methods: An introduction, Star Bright Services.

OECD (2011). Strategic Human Resource Management in OECD, Government at a Glance 2011, OECD Publishing.

Orodho, A. J. (2005). Essentials of Educational and Social Services Research Methods, Nairobi: Masola Publishers.

Orodho, A and Kombo, D (2002). Research Methods,Nairobi: Kenyatta University, Institute of Open Learning.

O'Reilly, C.A.III. (1991). Organizational Behavior: Where We've Been, Where We're Going. Annual Review of Psychology, 42, 427-458.

Penrose, E (1959). The Theory of the Growth of the firm, Oxford, Blackwell.

Price, A (2011). Human Resource Management, Cengage Learning EMEA. Public Service Commission (2014). Circular No. 14

Purcell, J. (2003). Understanding the People and Performance Link: Unlocking the Black Box. NY, CIPD Publishers.

Pynes, J. E. (2008). Human Resource Management for Public and Non-Profit Organizations: A Strategic Approach, John Wiley \& Sons.

Ritter, J. \& Anker, R. (2002). Good Jobs, Bad Jobs: Workers' Evaluations in Five Countries. International Labor Review, 141(4), $331-358$.

Salmela-Aro, K., Nurmi, J. (2004). Employees' Motivational Orientation and Well-Being at Work. Journal of Organizational Change Management, Vol. 17 No 5, pp. 471-489.

Schuler R. S. (1992). Strategic Human Resource management: Linking people with the needs of the business, Organizational Dynamics, Vol.21, No.1 pp. 18-32.

Schuler R. S. and Jackson, S.E. (2007). Strategic Human Resource Management: A Reader, London, UK: Blackwell Publishers.

Schwind H, Das H., and wagar T (2005.), Canadian Human Resource Management. A strategic Approach 7th edition, McGraw - Hill Ryerson

Soomro, R.B., Gilal, R.G., Jatoi, M.M. (2011), Examining the impact of human resources management (HRM) practices on employees' performance a case study of Pakistani commercial banking sector. Interdisciplinary Journal of Contemporary Research in Business, 3(1), 865.

Torrington et al. (2008). Human Resource Management, Pearson Education Ltd. 